\title{
Postcolonialism and Baltic Drama
}

\author{
LUULE EPNER
}

\section{Benedikts Kalnačs, $20^{\text {th }}$ Century Baltic Drama: Postcolonial Narratives, Decolonial Options. Bielefeld: Aisthesis Verlag, 2016.}

Postcolonialism belongs to the variegated family of post-notions, referring in most cases to a number of intellectual and cultural trends that started in the mid-2 $0^{\text {th }}$ century. It took shape as a response to the collapse of large colonial empires during that period, and sought to redefine their cultural legacy from the perspective of the colonized subject. Post-notions assuredly get their meaning from their root concept, in this case - from how narrow or broadly colonialism is defined. After (and in consequence of) the collapse of the Soviet Union in 1989-1991 and the restoration of independent national states the postcolonial approach gradually began to gain influence in the field of Soviet studies. Since the Soviet empire had been in many ways different from "classical" Western colonial regimes, this led to the need to broaden the definition of colonialism and to develop methodologies for investigating the Soviet experience. When a few years ago Epp Annus, one of the most active advocates for postcolonial approach to the Soviet regime and its legacy, observed that "the field of postcolonial studies has not seen Russian colonialism as part of its research agenda" (Annus 2011a: 441), then now the situation is much more promising ${ }^{1}$. It may even be claimed that a paradigm shift is underway, as evidenced by a large number of recent publications on relevant matters - among others, the special issue of the Journal of Baltic Studies (2016), and the monograph of Benedikts Kalnačs $20^{\text {th }}$ Century Baltic Drama: Postcolonial Narratives, Decolonial Options $(2016)^{2}$. The latter publication deserves special attention. It is the outcome of long research, summarizing many articles on Baltic drama, published by the author in 2006-2015, and was preceded by the monograph in Latvian Baltijas postkoloniālā dräma (Baltic postcolonial drama, 2011). The present paper focuses

1 Of course, the colonial experience of the Baltic nations is not limited to the Soviet era but includes centuries of German hegemony. One could speak even of three colonial powers in Baltic history: Baltic German, Tsarist Russian and Soviet colonialism.

2 Benedikts Kalnačs, $20^{\text {th }}$ Century Baltic Drama: Postcolonial Narratives, Decolonial Options. Bielefeld: Aisthesis Verlag, 2016. 
EPNER

on the contribution of this monograph to postcolonial studies, as well as to comparative literature, and comments on some issues of postcolonial research.

It has been repeatedly argued that both postcolonial and post-Soviet studies need to involve a comparative aspect (see, for instance, Annus 2011b). But despite the fact that research into history of the Baltic nations from the postcolonial perspective is a rapidly developing field, there is still a shortage of more specific cultural and literary studies. As regards the field of comparative literature, the monograph of Kalnačs stands out as one of the rather rare indepth studies of small literatures, published in English. This is even more rare since comprehensive studies of drama do not abound, to put it mildly - drama is frequently considered as a peripheral genre of literature. Such a comparative study requires (and demonstrates) profound expertise in local cultures and societal contexts, not to speak of good language skills. In addition, Kalnačs as a representative of the middle generation of researchers has a personal, direct experience of living under Soviet regime. Reliance on first-hand knowledge of Soviet and post-Soviet cultural life contributes to the reliability of his analyses.

Kalnačs formulates his main research issues in terms of (national) identity: "whether and in what contexts we can see Baltic cultures as agencies of Europe's internal others and in what ways Baltic identity has been determined by historical processes of foreign settlement, occupation, and colonization" (p. 14). To answer these questions, it is necessary to take a look also at the first steps of Baltic national theatre and drama in the second half of the $19^{\text {th }}$ century, but the main emphasis is placed on Soviet colonialism and the postSoviet decolonization. The book is divided into six chapters, preceded by a lengthy theoretical and historical introduction and followed by the afterword about postcolonialism in the drama of the $21^{\text {st }}$ century. The chapters tackle six facets of Baltic drama (or patterns of manifestations of anti-colonial thought, as explained on p. 57), providing examples from all three literatures, so that the comparative viewpoint comes clearly to the fore. The facets are termed as follows: the national (expressing the particularity of the culture), the philosophical (referring to the context of more global trends of thought), the historical (a tendency towards the preservation of established values), the contemporary (referring to representations of daily life and the return to realistic style), the absurd (including the possibility for anti-colonial protest), and the postcolonial (manifestations of post-independence feelings) (p. 57). These patterns combine and reverberate through various literary and theatrical practices during the $20^{\text {th }}$ century; however, the chapters roughly follow the line of development of Baltic drama from the beginning until today. Such a structure may somewhat simplify the complex, entangled literary processes, but provides a clear and easy-to-follow historical narrative. However, the comparative aspect 
could have been even more emphasized, e.g. by drawing parallels between drama texts from different time periods (chapters) - the more so, since the main periods and trends of the $20^{\text {th }}$-century Baltic drama are briefly (and a little repetitively) characterised already in the introduction of the book.

The author claims to have tried "to pay all three literatures the same range of attention, and to preserve a certain kind of balance among them" (p. 61). This aim is to a large extent achieved, although the relative extent of Latvian, Lithuanian and Estonian playwriting varies from chapter to chapter. For instance, the chapters "The National" and "The Philosophical" which examine the period from the mid-19 ${ }^{\text {th }}$ century to World War II lack examples from Lithuanian drama. The most obvious reason lies in the fact that even though Lithuania, Latvia and Estonia are frequently compared to three sisters (or sooner three brothers, when considering the widespread term of Soviet parlance "brother states"), their historical experience is not quite the same. While Latvians and Estonians had been ruled by (Baltic) Germans since the $13^{\text {th }}$ century, then Lithuania had been independent for most of its early history during the Grand Duchy of Lithuania and later in the Polish-Lithuanian Commonwealth that lasted until the late $18^{\text {th }}$ century. But after Lithuania had become part of the Russian empire in the $19^{\text {th }}$ century, national culture suffered a particularly strong pressure from the tsarist authorities. For this reason, Lithuanian professional theatre could not be established until the 1920s. Chapters devoted to the analysis of Soviet and post-Soviet drama are clearly more balanced, by reason of largely shared historical experience of the Baltic nations during that period.

Literary process can be described at various levels and with a varying focus on individual texts, writers and their work as a whole, literary genres, trends, periods, or else. The argument of the book under discussion proceeds from in-depth analysis of exemplary plays, in the first place. The analysis frequently relies on the relevant biographical data of the playwrights, and is supported by references to a range of reviews and studies. The plays are also linked to dominant literary trends, such as socialist realism in the Soviet period, and finally arranged into the narrative about the development of Baltic drama throughout the $20^{\text {th }}$ century.

It stands to reason that drama is an "amphibian" genre, since it operates in and adapts itself to literary and theatrical environments alike. Thus, when discussing plays, it is worth taking into account their actual theatrical context. The analysis of repertories from the aspect of the share of translations and their origin would probably be particularly productive for investigating cultural hierarchies in a colonial situation. In Kalnačs's book, the focus is on the changes in the literary field and theatre processes remain in the background. 
EPNER

Yet the theatrical context is not completely lacking; notably in the chapter "The Absurd" issues of how the plays were interpreted on stage and received by theatre audiences are vital for understanding their social impact.

In what follows I will comment briefly on the six key chapters of the book. "The National" describes the literary field at the turn of the $19^{\text {th }}$ and $20^{\text {th }}$ centuries, and focuses primarily on the Latvian playwright Rūdolfs Blaumanis. Life and work of Blaumanis, especially his plays The Prodigal Son (1893), Thunderstorm (1887) and In the Fire (1905) offer a good insight into the issue of national identity, as seen from two angles: Latvians versus Baltic Germans, the ruling class, and the Baltic nations versus Europe. Since Blaumanis (similarly to many other Baltic intellectuals) belonged to both German and indigenous cultures (p. 66), the main emphasis falls upon German colonialism. In Kalnačs' view, inner tensions which resulted from the "subaltern" standing of Blaumanis had a significant impact on his choice of subject matter and strategies of representation. In the fresh interpretation of The Prodigal Son Kalnačs demonstrates how the author's personal experience and his dilemmas are projected into fictional characters; this, in turn, helps to identify new, modernist features of the play.

Moving on to the early $20^{\text {th }}$ century, when European cultural and philosophical trends began to have ever greater impact on Baltic literatures, Kalnačs supplements the national with the philosophical aspect of representation. In the chapter "The Philosophical" the author argues that appropriation of Western cultural heritage (notably of the Bible ${ }^{3}$ ) was to a great extent motivated by the desire to be on a par with more developed European countries. The argument is supported by the comparative analysis of the work of the Latvian poet and playwright Jānis Rainis (Blow, Wind!, 1913, Joseph and His Brothers, 1919), and of the tragedy Judith (1921) by the Estonian writer A. H. Tammsaare. Kalnačs claims that striving for Europe can be regarded as an anti-colonial trend, as Lithuania, Latvia and Estonia were part of the Russian colonial empire at the time. The Estonian scholar Tiit Hennoste, contrarily, sees the discourse of Europeanization as a symptom of basically a colonial way of thinking, i.e. (unconscious) self-colonization (see Hennoste 2006) - the concept that has generated heated debates in Estonian criticism. I would rather agree with Kalnačs' commentary that a dialogue with modern Russian culture counterbalanced the processes of presumable self-colonization (p. 26, footnote 39). Besides, the writers' interest in indigenous folklore (as seen in Blow, Wind!

The use of Bible stories in itself does not differentiate between European and nonEuropean (Russian) cultural spaces, since the Bible belongs to the canon of Russian orthodoxy, too. 
by Rainis or The Werewolf by the Estonian August Kitzberg) also acted as a counterweight to European imaginings.

Lithuanian drama appears on stage only in the chapter "The Historical" which covers the period from the 1920 s to the 1980 s, i.e. the era of both national independence and Soviet colonialism. Kalnačs states that the representation of national history has been especially important for the identity formation of the Lithuanian nation (p. 108). His prime instances here are Skirgaila by Vincas Krève-Mickevičius (1922), The Shadow of the Giant by Balys Sruoga (1932), the historical trilogy by Justinas Marcinkevičius Mindaugas (1968), The Cathedral (1971) and Mažvydas (1977), and Barbora Radvilaité by Juozas Grušas (1972). These plays mostly represent heroic characters from the $13^{\text {th }}$ to $16^{\text {th }}$ centuries the era of close relations between Lithuania and Poland that in itself could not be defined as a colonial situation. Thus, the postcolonial approach operates on the assumption that representations of history refer to the contemporary colonial condition. This is definitely true of the Soviet period, when the usage of the "language of Aesop" (and the ability of the audiences to read it) became widespread, but is much less obvious in the period of independence. In view of this, the work of Marcinkevičius appears to be of most interest for me. Kalnačs shows that Marcinkevičius's model of representation was imbued with Soviet ideology, but at the same time the writer opposed the dominant doctrine of internationalism - this is a telling instance of postcolonial hybridity.

"The Contemporary", the longest chapter of the book, takes us back to the Stalinist period of the Soviet colonial regime (the 1940s and the 1950s). In this chapter Kalnačs discusses the notion of socialist realism, the official method of Soviet literature that was largely perceived as essentially alien to the local literary tradition in the Baltics. He introduces a range of plays from all three Baltic literatures; some of them exemplify the principles of socialist realism, some others - the return to the realistic portrayal of everyday life. During the Soviet thaw period the term "socialist realism" became increasingly ambiguous and was frequently used as a label in a kind of "hide and seek" play between authorities, critics and writers. It is also questionable to what extent local writers in reality followed the doctrine of socialist realism - here, one can speak of mimicry as a typical strategy of subalterns attempting to preserve their identity. In addition, artistic means of expression were refreshed and modernist trends began to appear in Soviet literature, too. A share of Soviet drama in the repertoire of the theatres was prescribed by the authorities (one third of all new productions, at minimum), but the theatres naturally tried to "furnish" this compulsory category as well as possible. So, new Soviet (Russian) plays that were staged in the theatres of Baltic republics most likely helped to re-establish realistic paradigm in local drama. We can see how complicated the literary 
EPNER

situation of the time was. Baltic literatures were located in the field of tension where goals and strategies of colonizers and colonized intricately combined.

Next chapter, entitled "The Absurd”, examines modernist innovation of the 1960s and provides instances from Estonian (Paul-Eerik Rummo's Cinderellagame, 1969) and Lithuanian drama (Kazys Saja's The Mammoth Hunt, 1968). Somewhat surprisingly Kalnačs bases his interpretations mainly on how folkloristic heritage has been adapted in these plays. This gives a fresh impression of Cinderellagame, usually interpreted in the framework of Western existentialism by Estonian critics. Concerning the reception of this play, Kalnačs suggests that "the colonization of minds" (p. 163) and the "strong impact of the established aesthetic norms" (p. 56) account for the negative attitude of a large section of the audience, in the first place. Here, the role of colonialism seems a bit overrated to me, as reluctance and negation are quite ordinary responses to unfamiliar avant-garde art, irrespective of the presence or absence of the colonial situation. Rummo himself has recalled that in the 1960s his modernist experiments led to conflicts not only with Soviet officials, but also with the nationally disposed traditionalists from among his compatriots (Rummo 2000: 34).

The last chapter "The Postcolonial" focuses on how postcolonial space and time manifest themselves in Baltic post-communist drama, in the period of sharp social and mental changes. The post-communist transition of the 1990s has been described as "Return to the Western World" (to quote the title of the sociological study, 1997). However, there was no easy way to "return" from the Soviet empire to the West, as the pre-war Western world the Baltic states belonged to had undergone substantial changes. By the same token, a dialogue with the experience inherited from the Soviet past continued to shape literary and artistic production, regardless of the end of Soviet colonization (p. 201). Exemplary authors here include Rūta Mežavilka, Māra Zālìte, Inga Ābele from Latvia (it is worthy of notice that all of them are female), Jaan Tätte and Jaan Undusk from Estonia; Lithuanian drama remains in the background in this chapter. The argument about playwriting in the period of newly established independence continues smoothly in the afterword, entitled "Postcolonialism, Postcommunism, and Textual Strategies of the $21^{\text {st }}$ Century Baltic Cultures", which could be read as one more chapter in the narrative of Baltic drama. The Lithuanian playwright Marius Ivaskevičius together with the Latvian stage director Alvis Hermanis form the focus of this chapter. (Let me remark that the documentary "theatre of biographies" of the Estonian stage director Merle Karusoo would have complemented the general picture very well.) In my view, the last chapter and the afterword of the book demonstrate most clearly that the postcolonial approach can explain how inner tensions and contradictions of 
decolonization processes are "translated" into plots and characters' behavioural patterns.

On the whole, the book is a valuable contribution to literary studies. Its focus alternates and varies (from country to country, among other things), and so does the conceptual framework. According to needs, postcolonial concepts are combined with many other approaches, like new historicism, world-system theory, autoethnography, not to speak of the comparative-historical method. This makes the argument more interesting and flexible, but at times slightly tends to become a bit incoherent. One may even ask whether or why postcolonial theory would be the most effective research tool for addressing cultural changes and intercultural communication, especially in the Soviet period. Could the quite popular and ideologically more neutral concept of cultural transfer offer an alternative $?^{4}$ There are surely connections between cultural transfer research and postcolonial studies, yet the former views cultural processes as mutual, and encourages research into cultural mixings, entanglements etc., whereas the postcolonial perspective is particularly sensitive to the issues of power and ideological matters. Thus, postcolonial studies tend to focus on hierarchical power relations that influence cultural mechanisms and make communication between colonizers and colonized asymmetrical. Here, the concept of hegemony, introduced by Antonio Gramsci and elaborated by Edward Said, could be most helpful, in particular for analysing cultural dynamics in the post-Stalinist period (the 1960s-1980s). The notion of hegemony (mentioned on p. 51) implies that relations between the dominant and the subordinated social classes are two-sided and power is exercised through negotiation rather (including, of course, propaganda of dominant ideology) than through direct repression. The subordinated classes (like colonized subjects) may, to a larger or lesser extent, embrace dominant values, but when the cultural sphere is controlled by hegemony, there is still room for counter-discourses and for subcultures. This is certainly true of the late Soviet period. Thus, the concept of hegemony suggests research into a variety of cultural strategies that involve an element of resistance and are characteristic of the postcolonial situation cultural hybridity, mimicry, etc.

The just mentioned concept of hybridity would possibly have needed further theoretical elaboration. Even though this is one of the most theorized

4 For instance, a historian Olaf Mertelsmann has made a case for the approach of cultural transfer versus postcolonialism in Estonian context, arguing that "Soviet culture had a universalistic and European approach, it was not totally different from Estonian culture". See http://www.utkk.ee/kirjanduskeskus/yritused/kirjanduskeskuse-teadusseminarid.html?id=50 
EPNER

notions in postcolonial studies, it could hardly do full justice to the specificity of colonized cultures. Indeed, one can argue that 'there is no 'clean' or 'basic' culture whatsoever as a contrast to 'hybrid' culture - all cultures are in a sense mixed" (Hasselblatt 2008: 22). If literature and art themselves are hybrid constructions, then there is a risk to flatten out real cultural differences under this umbrella term. Many-sided cultural influences further complicate the picture. For instance, in the 1950s and 1960s Estonian literature moved closer to Western patterns, but also got impulses from Russian literature of the young generation who was in its turn to certain extent influenced by Western trends. In Latvia, the theatre of the 1960s and 1970s was a kind of spiritual resistance to Sovietization, but at the same time the main source of influences for Latvian directors was Russian modern theatre (see Zeltina 2012: 23). The literary field of the $19^{\text {th }}$ century offers an equally complex picture of multiple cultural identities and entanglements of (Baltic) German, Russian and indigenous cultures.

One more key concept within and outside postcolonial research is the Other. The cultural Other can be defined as a cultural community with which we lack a critical mass of common texts and practices (Raud 2013: 76). The Other is being perceived as a stranger, often also as incomprehensible and even dangerous. The dichotomization and essentialisation of the natives as "others" definitely belong to the rhetoric of the colonial discourses (Plath 2008: 65). This is clearly visible in the discourse of Baltic Germans - to legitimate German (colonial) domination, Estonians and Latvians were described as "other". According Ulrike Plath, in the 19th century Estonians were even seen as "Europe's last savages". Compared to the Latvian people, Estonians were perceived as more exotic, partly due to linguistic factors: the belonging of the Estonian language to the Finno-Ugric language family was a good basis for "othering" Estonians, and this was used to construct an alternative, boreal cultural space (Plath 2008: 50-51). Thus, the idea of Baltic cultures being peripheral, other cultures within European cultural space has a long history. In the monograph of Kalnačs the focus shifts to the relationship between the Baltics and Europe already in the first chapter, in the subchapter "The Baltic Provinces as Europe's Internal Others: A History of Dependency", followed by the analysis of Blaumanis's drama In the Fire through the concept of autoethnography which refers to the texts that the others construct in response to European representations (p. 76).

The distinction between hybridity resulting from the blending of heterogeneous elements and internal (implied) hybridity of seemingly homogeneous discourses (see Grishakova 2013) could be helpful for more detailled analysis of this concept. 
The question of whether we can see Baltic cultures as "agencies of Europe's internal others" (p. 14) has not lost its relevance even today; quite to the contrary, it keeps evoking mixed feelings from both sides. Kalnačs contends that the whole Eastern Europe is in search of its identity and is torn between cultural stability and marginalized subalternity (p. 198), while the decolonization processes seem to intertwine with Western neocolonialism. The Baltic states have joined the European community and are widely regarded as an exemplary case of successful integration with Europe; nevertheless, many people experience ambivalent feelings towards Europe. As to Estonia, the title of the much-translated novel by Tõnu Õnnepalu Border State (1993) has become a popular symbol for post-Soviet Estonia as a zone where East and West meet. It is noteworthy that Onnepalu's image means lying at the margin rather than in-between: with the restoration of independence Estonia, the formerly westernmost republic of the Soviet Union ${ }^{6}$, turned into the easternmost state of (Western) Europe. As a part of Europe, the "border states" are at the same time subjected to global processes, such as massive migration, rise of multiculturalism, etc., which threaten to destabilize traditional cultural and national identities. Thus, the controversy between nativist and cosmopolitan (European) nationalism (see Peiker 2016) seems not to fade but rather to intensify, and the transnational European identity, promoted by the ongoing project of European integration, appears to be the problem rather than the solution. Among others, the postcolonial perspective could enable better understanding of the present developments in the Baltic republics.

\author{
Luule Epner \\ luule.epner@ut.ee \\ Tartu Ülikool \\ Kultuuriteaduste ja kunstide instituut \\ Teatriteaduse õppetool \\ Ülikooli 16-111 \\ 51014 Tartu \\ EESTI/ESTONIA
}

6 The formerly widespread image of the Baltics as „Soviet West” gives a rather paradoxical connotation to the concept of Soviet colonialism. 
EPNER

\section{References}

Annus, E. 2011a. The Conditions of Soviet Colonialism. - Interlitteraria, 16, no. 2, 441-450.

Annus, E. 2011b. Postkolonialismi pealetung post-sovetoloogias: kas paradigmamuutuse künnisel? - Methis, 7, 10-25.

Grishakova, M. 2013. Complexity, Hybridity, and Comparative Literature. - CLCWeb: Comparative Literature and Culture, 15:7.

Hasselblatt, C. 2008. Rahvuskultuuri paradoks ning eesti keele tähtsus. - Rahvuskultuur ja tema teised. Tallinn: Underi ja Tuglase Kirjanduskeskus, 13-22.

Hennoste, T. 2006. Noor-Eesti kui lõpetamata enesekoloniseerimisprojekt. - NoorEesti 100. Kriitilisi ja võrdlevaid tagasivaateid. Tallinn: Tallinna Ülikooli kirjastus, 9-38.

Peiker, P. 2016. Estonian Nationalism Through the Postcolonial Lens. - Journal of Baltic Studies, 1-20.

Plath, U. 2008. „Euroopa viimased metslased”: eestlased saksa koloniaaldiskursis 1770-1870. - Rahvuskultuur ja tema teised. Tallinn: Underi ja Tuglase Kirjanduskeskus, 37-66.

Raud, R. 2013. Mis on kultuur? Sissejuhatus kultuuriteooriatesse. Tallinn: Eesti Keele Sihtasutus, Tallinna Ülikooli kirjastus.

Rummo, P. 2000. Isiklikku. - Taasleitud aeg / Kadonneen ajan arvoitus. Tartu Ülikooli eesti kirjanduse oppetooli toimetised 2. Tartu, 33-39.

Zeltiña, G. 2012. Introduction and General Background. - Theatre in Latvia. Ed. By Guna Zeltina. Riga: Institute of Literature, Folklore and Art, 7-28. 